\title{
ANALYSIS OF CELL SAVER USE AND MORTALITY IN LIVER TRANSPLANT
}

\author{
Análise do uso do Cell Saver e mortalidade no transplante hepático \\ André Ibrahim David, Catiana Mitica Gritti, André Gustavo Santos Pereira, Tiago Emanuel de Souza, \\ Felipe Sbrolini Borges, Angela Caputi, Arnaldo Bernal, Gilberto Peron, Jorge Marcelo Padilla Mancero
}

\begin{abstract}
Introduction: Liver transplantation is considered the best treatment for irreversible liver disease. Due to the complexity of the procedure generally multiple blood transfusions are required. One option to reduce this need is the use of Cell Saver providing blood cell recovery and reinfusion. Purpose: to evaluate mortality in the number of washed red blood cell units recovered by Cell Saver and perioperative mortality. Methods: Data collection of transplant patients using CellSaver on the period from July 2014 to February 2017. Results: Performed 56 liver transplants, the diagnosis prevalent was liver cirrhosis by hepatitis $C$ virus $(37,5 \%)$. Of these $45(80,4 \%)$ of the transplants used Cell Saver, which had a median MELD of 24,5 (range 7-50). Taking into account the use of Cell Saver in washed red blood cell units and recovered notes a median of four (range 1-45). 12 died (26,7\%), the average of these MELD was 25,5 (range 1-50) and the use of washed red blood cell and recovered was a median of 4,5 . Conclusion: Patients who died used a similar amount of washed and recovered erythrocyte units.
\end{abstract}

Keywords: Transplant, Liver, Transfusion, Infusion, Cell Saver

\section{Institution:}

Unidade de Transplante Renal, Hospital Beneficência Portuguesa São Paulo/SP - Brasil

\section{Correspondence:}

André Ibrahim David

End.: Rua Pamplona, 1808 / 52 - CEP 01405-002 - São Paulo/SP

Tel.: +551198133-5943

E-mail: andredavidmd@gmail.com

Recebido em: 01/03/2017

Aceito em: 29/04/2017

\section{INTRODUCTION}

Liver transplantation is considered the best treatment for irreversible liver disease. ${ }^{1}$ In our environment, the main etiologies of cirrhosis are hepatitis $C$ virus and alcoholic. Clinical treatment interferes little in the survival of these patients. When complications such as encephalopathy, gastrointestinal bleeding or uremia are present, the five year survival rate is less than $50 \%{ }^{1}$ 
Liver transplantation is associated with of blood products and increase the recipient exposure to viral, bacterial and protozoal infections associated with transfusions, events that may be undesirable in immunosuppressed patients. ${ }^{2}$ Homologous transfusions during liver transplantation are associated with increased morbidity and mortality in the postoperative period. During this procedure, the abnormal hemorrhage typically occurs as a result of haemostatic dysfunction and portal hypertension, related on proper operative procedure. The etiology of hemostasis anomalies is multifactorial, including platelets deficit and coagulation factors related to liver disease. ${ }^{3}$

One option to reduce this transfusions need is the use of Cell Saver. The blood conservation techniques, the Cell Saver systems, allow to process the aspirated blood from the surgical field and infuse it on the patient. ${ }^{4,5}$ In this way, you can recover up to $60 \%$ of the lost red blood cells, assuming auto transfusion intraoperative technique. The effectiveness of the technique depends on a dedicated multidisciplinary team focused on perfusionist that ensures maximum reuse. ${ }^{6}$ The recovered blood processing involves separation, washing and centrifugation (concentration) of blood aspirated from the surgical field and mixed with an anticoagulant. The result is a red cell product recovered blood with a hemoglobin> $17 \mathrm{~g} / \mathrm{dL}$. A leukocyte depletion filter is used for reinfusion into the patient.

\section{PURPOSE}

Analyze perioperative mortality related to the number of red bloods cells packs saved with the Cell Saver.

\section{MÉTHODS}

Data were retrospectively collected from 56 transplants performed in Beneficência Portuguesa Hospital of Sao Paulo. Analyzed data of auto transfusion technique through the Cell Saver intraoperative in the period July 2014 to February 2017. The method used was the study of median red blood cells washed related to patient mortality.

\section{RESULTS}

The results obtained by analysis of 56 liver transplants, where the prevalent diagnosis was cirrhosis of the following etiologies: Hepatitis C virus with 21 patients (38\%); Alcohol, 12 patients (21\%); Nonalcoholic steatohepatitis (NASH) with four patients (7\%); Hepatitis B Virus, two patients (4\%); Fulminant hepatic failure with two patients (4\%) and Budd Chiari, one patient $(2 \%)$.

The Cell Saver was used in 45 patients $(80 \%)$ that had a median MELD of 24,5 (range 7-50). Taken into account the use of Cell Saver in washed red blood cell units and recovered noticed a median of four (range 1-45). Survived 44 patients $(79 \%)$ in which they used the Cell Saver, 12 died (21\%), but with a higher median MELD in the amount of 31 (range 13-50) and the use of washed and recovered red blood cells had a median of 4,5 (range 2-45).

\section{DISCUSSION}

Liver transplantation is still a challenging procedure even for experienced surgeons being welcome all technologies for better survival. ${ }^{7}$ Therefore, the Cell Saver is a good tool to manage the cirrhotic intraoperatively. Once reduces the demand for heterologous transfusions and reduces exposure to infectious, viral, bacterial and protozoa diseases. ${ }^{8,9}$ But Cell Saver per se is a risky tool if you need to use it more than four red blood packs. ${ }^{1}$

Patients who died had a median higher MELD and used 4,5 recovered red blood packs (median). Cell Saver is a good device, but technical surgery and hemostasis still are the keys of the liver transplant success. ${ }^{10,11}$

\section{CONCLUSION}

Patients who died used a similar amount of washed and recovered erythrocyte units. The Cell Saver is a good tool for the cirrhotic, having no relationship with the mortality in our series. 
André Ibrahim David, Catiana Mitica Gritti, André Gustavo Santos Pereira, Tiago Emanuel de Souza,Felipe Sbrolini Borges, Angela Caputi, Arnaldo Bernal, Gilberto Peron, Jorge Marcelo Padilla Mancero

\section{RESUMO}

Introdução: O transplante hepático é considerado o melhor tratamento para doença hepática irreversível. Devido à complexidade do procedimento, múltiplas transfusões de sangue são necessárias. Uma das opções para reduzir essa necessidade é o uso do Cell Saver, que fornece recuperação e reinfusão de células sanguíneas. Objetivo: avaliar a mortalidade no número de unidades de hemácias lavadas recuperadas pelo Cell Saver e a mortalidade perioperatória. Métodos: Coleta de dados de pacientes transplantados que utilizaram Cell Saver no período de Julho de 2014 a Fevereiro de 2017. Resultados: Realizados 56 transplantes hepáticos com diagnóstico prevalente de cirrose hepática pelo vírus da hepatite C $(37,5 \%)$. Destes, $45(80,4 \%)$ dos transplantes utilizaram Cell Saver, com MELD médio de 24,5 (intervalo 7-50). Levando em conta o uso de Cell Saver em unidades de hemácias lavadas e notas recuperadas, ocorreu uma mediana de quatro (intervalo 1-45). 12 morreram (26,7\%); a média MELD destes foi de 25,5 (intervalo 1-50) e o uso de hemácias lavadas e recuperadas teve uma mediana de 4,5. Conclusão: Pacientes que morreram utilizaram quantidade semelhante de unidades de eritrócitos lavadas e recuperadas.

Descritores: Transplante, Fígado, Transfusão, Infusão, Cell Saver.

\section{REFERENCES}

1. Sankarankutty AK, Teixeira AC, Souza FF, Mente ED, Oliveira GR, Almeida RC, Andrade CM, Origuella EA, Silva Ode C. Impact of blood salvage during liver transplantation on reduction in transfusion requirements. Acta Cir Bras. 2006;21 Suppl 1:44-7.

2. Feltracco P, Brezzi ML, Barbieri S, Galligioni H, Milevoj $\mathrm{M}$, Carollo $\mathrm{C}$, Ori C. Blood loss, predictors of bleeding, transfusion practice and strategies of blood cell salvaging during liver transplantation. World J Hepatol 2013. Jan 27;5(1):1-15.

3. Carless PA, Henry DA, Moxey AJ, O'connell DL, Brown T, Fergusson DA. Cell salvage for minimising perioperative allogeneic blood transfusion. Cochrane Database Syst Rev. 2006 Oct 18;(4)

4. Kırnap M, Tezcaner T, Ayvazoğlu Soy HE, Akdur A, Yıldırım S, Torgay A, Moray G, Haberal M. Efficacy of cell saver use in living-donor liver transplant. Exp Clin Transplant. 2015 Apr;13 Suppl 1:315-7

5. Feltracco P, Michieletto E, Barbieri S, Serra E, Rizzi S, Salvaterra F, Cillo U, Ori C. Microbiologic contamination of intraoperative blood salvaged during liver transplantation. Transplant Proc. 2007 Jul-Aug;39(6):1889-91.

6. Araujo RL, Pantanali CA, Haddad L, Rocha Filho JA, D'Albuquerque LA, Andraus W. Does autologous blood transfusion during liver transplantation for hepatocellular carcinoma increase risk of recurrence? World J Gastrointest Surg. 2016 Feb 27;8(2):161-8.
7. Schumann R, Mandell MS, Mercaldo N, Michaels D, Robertson A, Banerjee A, Pai R, Klinck J, Pandharipande $\mathrm{P}$,Walia A. Anesthesia for liver transplantation in United States academic centers: intraoperative practice. J Clin Anesth. 2013 Nov;25(7):542-50.

8. Ko JS, Gwak MS, Kim GS, Na YR, Lee SK. The comparisons of hepatitis $C$ virus RNA level between intraoperative blood salvage (cell saver) and systemic hepatitis $C$ virus RNA kinetics during liver transplantation. Transplant Proc. 2014 Jun;46(5):1430-1.

9. Boin IF, Leonardi MI, Luzo AC, Cardoso AR, Caruy CA, Leonardi LS. Intraoperative massive transfusion decreases survival after liver transplantation. Transplant Proc. 2008 Apr;40(3):789-91.

10. Hüser N, Aßfalg V, Reim D, Novotny A, Thorban S, Cheng Z, Kornberg A, Friess H, Büchler P, Matevossian E. Heparininduced thrombocytopenia (HIT II) in liver transplant recipients: a retrospective multivariate analysis of prognostic factors. Transpl Int. 2012 Jul;25(7):739-4.

11. Liang TB, Li DL, Liang L, Li JJ, Bai XL, Yu W, Wang WL, Shen Y, Zhang M, Zheng SS. Intraoperative blood salvage during liver transplantation in patients with hepatocellular carcinoma: efficiency of leukocyte depletion filters in the removal of tumor cells. Transplantation. $2008 \mathrm{Mar}$ 27;85(6):863-9. 